\title{
SELECTED GENDER GAP INDICATORS - COMPARISON OF V4 COUNTRIES WITHIN EU CONTEXT
}

\author{
HANA ŘEZANKOVÁ \\ University of Economics, Prague, Faculty of Informatics and Statistics, \\ Department of Statistics and Probability, W. Churchill sq. 4, Prague 3, Czech Republic \\ email: hana.rezankova@vse.cz
}

\section{ZUZANA KŘEČKOVÁ}

University of Economics, Prague, Faculty of International Relations, Department of Retailing and Commercial Communications,

W. Churchill sq. 4, Prague 3, Czech Republic email: zuzana.kreckova@vse.cz

\begin{abstract}
The paper examines similarities and distinctions of EU countries based on the Global Gender Gap Index and its four subindexes (Economic Participation and Opportunity, Educational Attainment, Health and Survival, Political Empowerment) reported in 2016. Multivariate statistical methods (cluster analysis and discriminant analysis) are applied for this purpose. Influence of individual subindexes on results of statistical analyses is discussed. The groups of countries are identified and models for country classification are proposed and compared. Changes in index values, as well as, relationships between selected gender and economic indicators (Global Competitiveness Index and GDP per capita) are investigated for period 2006 to 2016. Special attention is paid to the Visegrad Group countries within EU context.
\end{abstract}

Key words: gender gap indicators, multivariate statistical methods, EU countries

JEL Codes: J71, O57, O44, F43

DOI: 10.15611/amse.2017.20.31

\section{Introduction}

It is obvious that the importance of women in economic areas is growing globally. Women are more involved in the labor market; in many countries they achieve higher levels of education than men, they decide on a greater proportion of household expenditure. On the other hand, it is possible to evaluate their position as unfair, because even though their proportion is higher in sample of higher level education graduates, they rarely occupy the highest positions in political and corporate sphere, their incomes are generally lower than those of men, even for identical work and they even tend to be discriminated on the labor market.

The gender inequality is reflected in many scientific articles, even within Visegrad countries. Scientists studied discrimination on the labor market (Žofková, 2014; Brožová, 2006; Mishtal, 2009, Pailhe, 2000; Joliffe and Campos, 2005), on consequences of reconciling work with family care (Brožová, 2015; Fodor and Kispeter, 2014; Heinen and Wator, 2006; Křŕžková and Vohlídalová, 2009), horizontal segregation (Picka, 2014; Piscová, 2003), gender balance in the field of remuneration (Vlachová, 2014; Mysíková, 2012; Balcar, 2012; Pytlíková, 2012; Křřžková et al., 2010) and vertical segregation (Křečková, 2013; Křečková Kroupová, 2009; Piscová, 2003). Relationship of gender gap, competitiveness and 
sustainability of economy for selected countries was analyzed in (Křečková Kroupová and Řezanková, 2016).

From 2006, the World Economic Forum (WEF) evaluates and publishes the Global Gender Gap Index (GGG index, further "GGI"). This index is the non-weighted average of four subindexes: Economic Participation and Opportunity, Educational Attainment, Health and Survival, and Political Empowerment. Each subindex is based on several variables (the numbers of variables range from 2 to 5). Subindex Economic Participation and Opportunity (further economy) is the most complex; it includes a ratio of female labor force participation over male value, wage equality between women and men for similar work, a ratio of female estimated earned income over male value, a ratio of female legislators, senior officials and managers over male value, and a ratio of female professional and technical workers over male value. Subindex Educational Attainment (further education) is based on the ratio of women and men in primary, secondary and tertiary education, and moreover the ratio of female literacy rate over male value. Subindex Health and Survival (further health) reflects the sex ratio at birth and a ratio of female healthy life expectancy over male value. Subindex Political Empowerment (further politics) includes a ratio of females with seats in parliament over male value, females at ministerial level over male value, and number of years with a female head of state (last 50 years) over male value. The latest published report measuring values in 2016 mapped 144 countries worldwide.

In terms of level of economy advancement WEF monitors competitiveness of countries by using its Global Competitiveness Index (GCI), which integrates both macroeconomic and microeconomic aspects of competitiveness. The index consists of 110 variables, grouped into 12 pillars that define areas important for competitiveness of a country. The pillars are grouped into three areas: basic requirements, efficiency enhancers and innovation and sophistication factors. Relative weights differ by categories of specific countries. Area basic requirements covers these pillars with respective weight: 1 . Institutions $(25 \%), 2$. Infrastructure $(25 \%)$, 3. Macroeconomic environment (25\%), 4. Health and primary education (25\%). Area efficiency enhancers covers pillars: 5. Higher education and training (17\%), 6. Goods market efficiency $(17 \%)$, 7. Labor market efficiency $(17 \%)$, 8. Financial market development (17\%), 9. Technological readiness (17\%), and 10. Market size (17\%). Area innovation and sophistication factors covers pillars: 11 . Business sophistication $(50 \%)$ and 12 . Innovation (50\%). WEF has been publishing GCI index yearly since 2004. The last published report surveyed 138 countries.

The aim of the paper is to assess development of GGI index and its four subindexes and the role of gender imbalances (GGI index) on competitiveness (GCI index) and economic prosperity (GDP per capita) of Visegrad countries. This paper focuses on Visegrad countries within the context of EU in time period 2006-2016.

\section{Development in the EU Countries}

In this section, development of GGI and its subindexes is characterized by mean, standard deviation, minimum and maximum values in even years of the period 2006-2016 (Tables 15). We can see that the smallest mean values and concurrently the greatest variability is in the case of the politics subindex during the whole period (the minimal value in this period is 0.031 and the maximal value is 0.616 ; the standard deviation is about 0.14 ). We can find the highest values for the education subindex. In 2006, there were six EU countries that achieved the value 1, in 2016 there were 12 countries with this value. However, the smallest variability and stable values were in case of the health subindex (the standard deviation was 0.004 during the whole period). 
Table 1: Statistics of GGI in EU countries in 2006-2016

\begin{tabular}{lcccccc}
\hline Statistic & 2006 & 2008 & 2010 & 2012 & 2014 & 2016 \\
\hline Mean & 0.700 & 0.714 & 0.720 & 0.724 & 0.733 & 0.735 \\
Standard deviation & 0.043 & 0.039 & 0.042 & 0.047 & 0.047 & 0.044 \\
Coeff. of variation & 0.061 & 0.055 & 0.058 & 0.065 & 0.065 & 0.060 \\
Minimum & 0.643 & 0.663 & 0.664 & 0.667 & 0.671 & 0.664 \\
Maximum & 0.813 & 0.820 & 0.826 & 0.845 & 0.845 & 0.845 \\
\hline
\end{tabular}

Source: Own analysis based on World Economic Forum (2006, 2008, 2010, 2012, 2014, 2016).

Table 2: Statistics of the economy subindex in EU countries in 2006-2016

\begin{tabular}{lcccccc}
\hline Statistic & 2006 & 2008 & 2010 & 2012 & 2014 & 2016 \\
\hline Mean & 0.632 & 0.666 & 0.685 & 0.694 & 0.704 & 0.698 \\
Standard deviation & 0.065 & 0.056 & 0.060 & 0.068 & 0.064 & 0.056 \\
Coeff. of variation & 0.103 & 0.083 & 0.088 & 0.097 & 0.091 & 0.081 \\
Minimum & 0.510 & 0.561 & 0.543 & 0.550 & 0.569 & 0.574 \\
Maximum & 0.734 & 0.784 & 0.770 & 0.815 & 0.805 & 0.802 \\
\hline
\end{tabular}

Source: Own analysis based on World Economic Forum $(2006,2008,2010,2012,2014,2016)$.

Table 3: Statistics of the education subindex in EU countries in 2006-2016

\begin{tabular}{lcccccc}
\hline Statistic & 2006 & 2008 & 2010 & 2012 & 2014 & 2016 \\
\hline Mean & 0.992 & 0.996 & 0.996 & 0.995 & 0.998 & 0.994 \\
Standard deviation & 0.014 & 0.004 & 0.004 & 0.005 & 0.003 & 0.011 \\
Coeff. of variation & 0.014 & 0.004 & 0.004 & 0.005 & 0.003 & 0.011 \\
Minimum & 0.931 & 0.989 & 0.988 & 0.978 & 0.992 & 0.953 \\
Maximum & 1.000 & 1.000 & 1.000 & 1.000 & 1.000 & 1.000 \\
\hline
\end{tabular}

Source: Own analysis based on World Economic Forum (2006, 2008, 2010, 2012, 2014, 2016).

Table 4: Statistics of the health subindex in EU countries in 2006-2016

\begin{tabular}{lcccccc}
\hline Statistic & 2006 & 2008 & 2010 & 2012 & 2014 & 2016 \\
\hline Mean & 0.976 & 0.976 & 0.976 & 0.976 & 0.975 & 0.976 \\
Standard deviation & 0.004 & 0.004 & 0.004 & 0.004 & 0.004 & 0.004 \\
Coeff. of variation & 0.004 & 0.004 & 0.004 & 0.004 & 0.004 & 0.004 \\
Minimum & 0.969 & 0.966 & 0.970 & 0.970 & 0.968 & 0.970 \\
Maximum & 0.980 & 0.980 & 0.980 & 0.980 & 0.980 & 0.980 \\
\hline
\end{tabular}

Source: Own analysis based on World Economic Forum $(2006,2008,2010,2012,2014,2016)$.

Table 5: Statistics of politics subindex in EU countries in 2006-2016

\begin{tabular}{lcccccc}
\hline Statistic & 2006 & 2008 & 2010 & 2012 & 2014 & 2016 \\
\hline Mean & 0.201 & 0.219 & 0.223 & 0.230 & 0.256 & 0.270 \\
Standard deviation & 0.138 & 0.128 & 0.134 & 0.137 & 0.142 & 0.139 \\
Coeff. of variation & 0.684 & 0.583 & 0.598 & 0.594 & 0.556 & 0.516 \\
Minimum & 0.052 & 0.032 & 0.031 & 0.057 & 0.064 & 0.035 \\
Maximum & 0.550 & 0.558 & 0.569 & 0.616 & 0.616 & 0.607 \\
\hline
\end{tabular}

Source: Own analysis based on World Economic Forum (2006, 2008, 2010, 2012, 2014, 2016). 


\subsection{Development in the Visegrad Group Countries}

The group of Visegrad countries was specially analyzed given its recent joint history in political and economic development. The process of transformation started in all these countries in nearly the same time and all four counties were facing the same challenges in political, economic and whole society challenges to be able to join European Union and become economically competitive while maintaining social stability and social peace in these rapidly changing historical period since the beginning of 1990s. Given all the complexity, gender balance across society does not seem to be the priority at any of V4 countries. Even though all the countries joined EU already in May 2004, all of them are lagging behind the gender equality compared to previous EU members.

Figures 1-3 show development of GGI and economy and politics subindexes in the Visegrad group countries in the period 2006-2016. Due to small differences in case of education and health subindexes, their values are not graphically presented.

Performance of GGI index among Visegrad countries shows improvement only in case of Poland, other three countries express only minimal to none improvements over the time period 2006-2016. Poland's GGI was all time the best, as well as growing since 2007. Slovakia started with the second best position 0.6757 in 2006 , but ended at 0.679 with minimum fluctuations over the time period 2006-2016. The Czech Republic started at 0.6712 and showed improving trend till 2010, when country was hit by economic crisis. Following years show steady decline of GGI till value 0.6737 in 2014, but years 2015 and 2016 show all time improvement till value 0.69 in 2016 . Hungary started with the worst V4 position 0.6698 in 2006 followed by improving trend, peaking at 0.6879 in 2009 , and decline to all time worst 0.6642 in 2011 . The last value 0.669 in 2016 brings Hungary back to starting position level.

Figure 1: Development of GGI index at Visegrad countries in 2006-2016

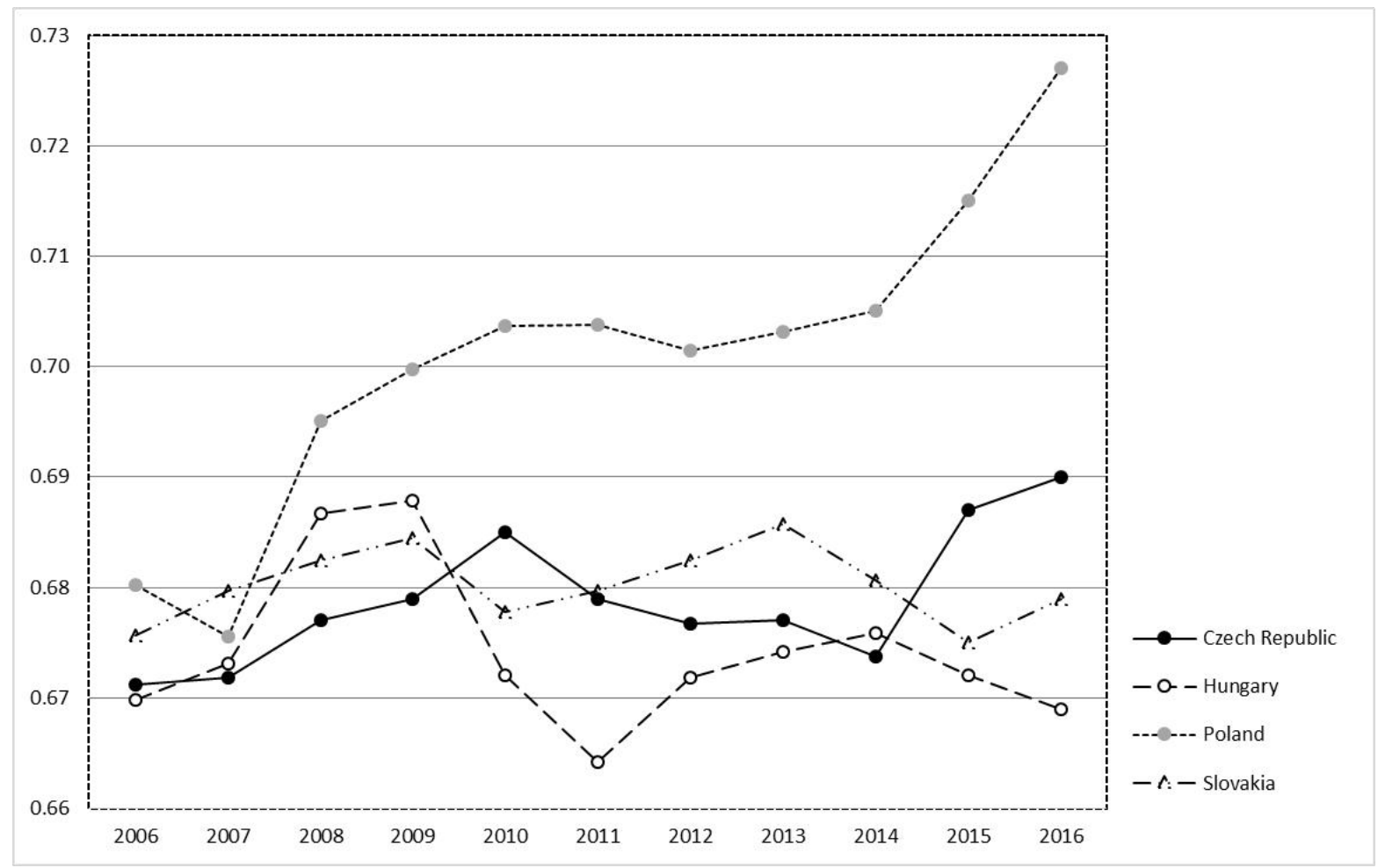

Source: Own analysis based on World Economic Forum (2006-2016).

There are two out of four subindexes that show little to none explanatory significance for the whole GGI index. These subindexes are education and health. Values for subindex 
education in V4 countries range from 0.999 to 1.000 and values for subindex health in V4 countries range from 0.973 to 0.9796 in time period 2006-2016. Hence, further focus will be on two remaining subindexes, economy and politics, that are drivers of the overall value of GGI index.

Subindex economy was fluctuating between 0.5961 (Czech Republic in 2011) and 0.69 (Poland in 2016) in time period 2006-2016. The best performing country was on average Hungary, the worst performing was the Czech Republic, and position of Slovakia was on average stagnating. However, Poland shows steady improving trend over this time period, ending with the best value of 0.69 among the V4 countries in 2016, which is also the highest over the time period 2006-2016.

Subindex politics was fluctuating between 0.1403 (Hungary in 2011) and 0.238 (Poland in 2016) in time period 2006-2016. The best performing country was in every year Poland, the worst performing was Hungary (with exception of years 2008 and 2009). Values for the Czech Republic and Slovakia were fluctuating between Poland and Hungary. And again, Poland shows steady improving trend over this time period, ending with the best value of 0.238 among the V4 countries in 2016, which is also the highest over the time period 20062016.

Interesting is also comparison of V4 countries in global spectrum sequence. It shows that even though some of subindexes are reaching quite satisfying level in the measured scale, in global comparison we can see that there are many countries reaching either the same level or even better. Thus, we can see that V4 countries are both not among the world leaders of gender equality, but also we can see that their global position is relatively worsening.

Figure 2: Development of subindex economy at Visegrad countries in 2006-2016

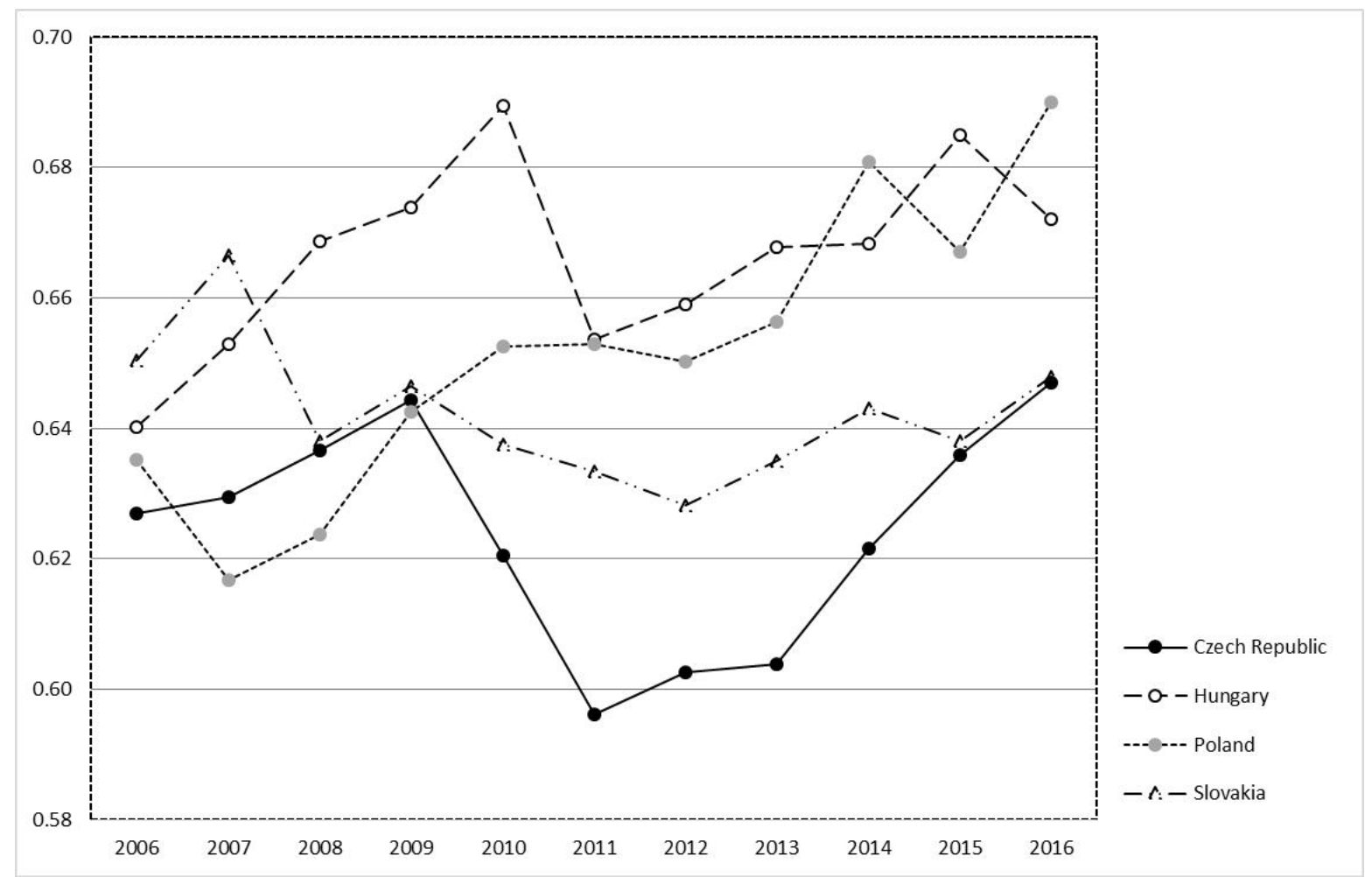

Source: Own analysis based on World Economic Forum (2006-2016). 
Figure 3: Development of subindex politics at Visegrad countries in 2006-2016

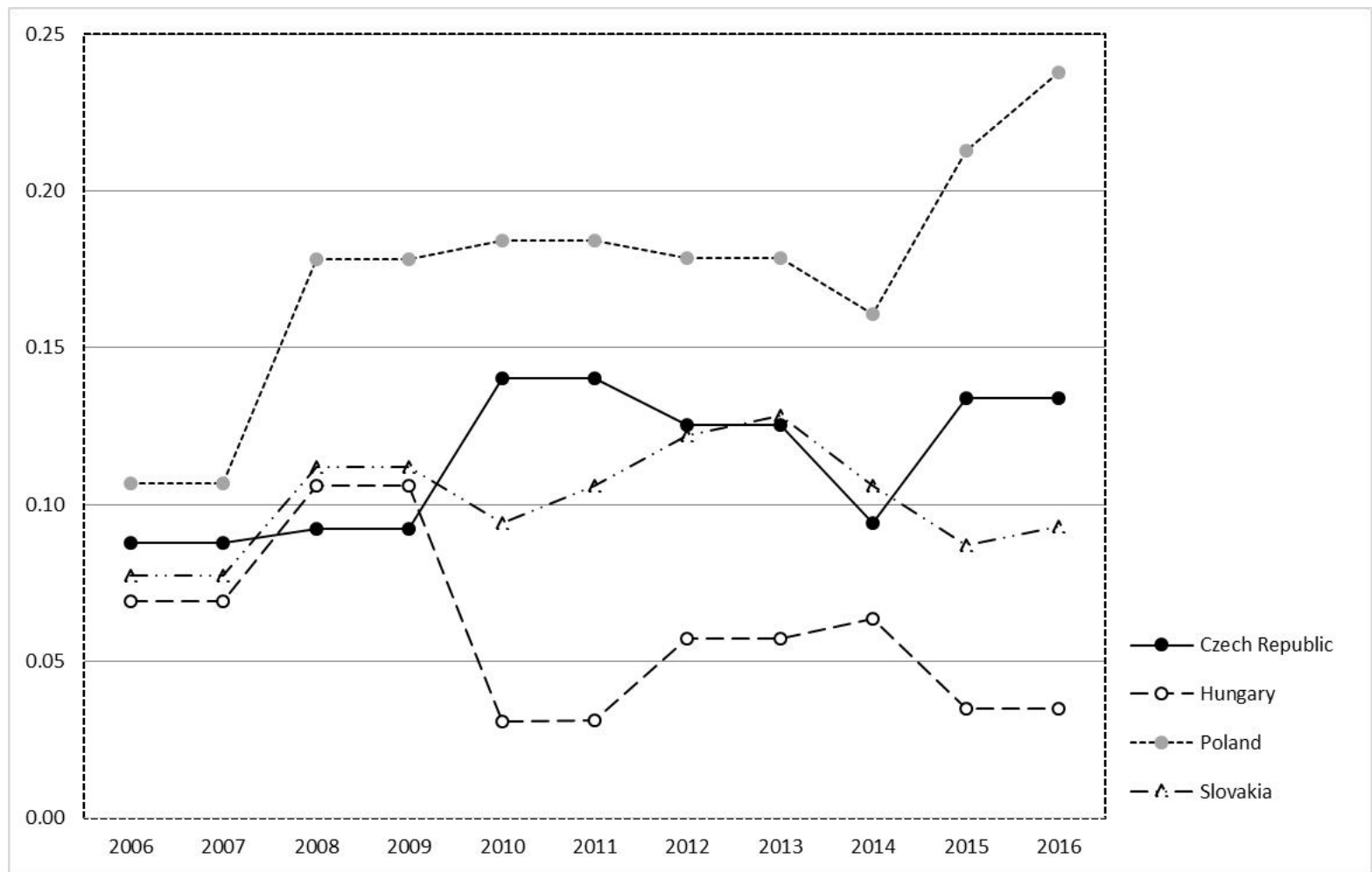

Source: Own analysis based on World Economic Forum (2006-2016).

Figure 4: Position of V4 countries in GGI indicator in global comparison in 2006-2016

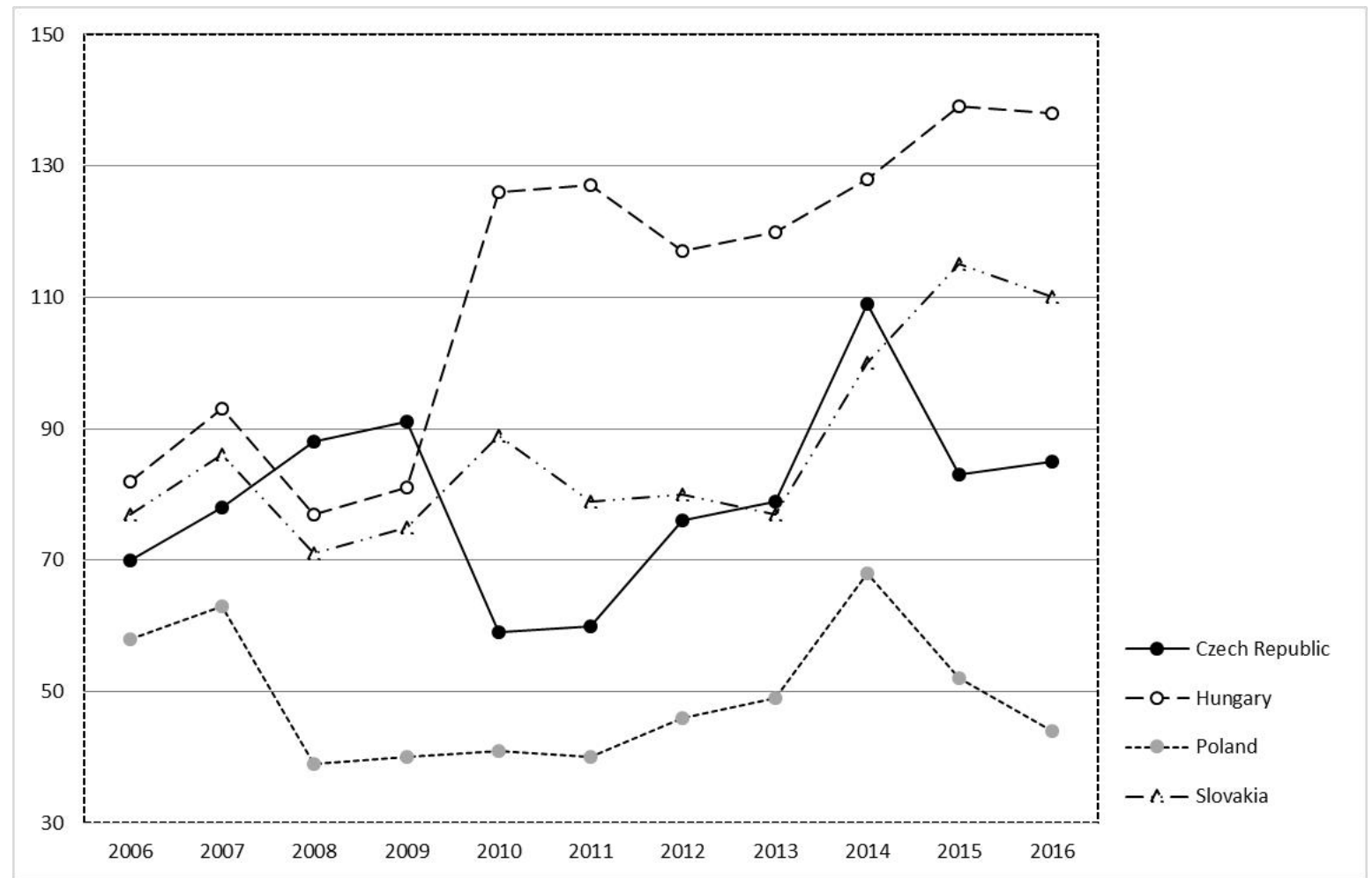

Source: Own analysis based on World Economic Forum (2006-2016).

The position of V4 countries in GGI index compared to other countries globally has been steadily worsening over the whole period 2006-2016, see Figure 4. Starting from position 44 
(Poland) to 55 (Hungary) in 2006, three of V4 countries closed at 77 (Czech Republic) to 101 (Hungary) position globally in 2016, while compared within the sample of 144 countries. There was one exceptions to this trend represented by slight improvement in the Czech Republic in 2015 and 2016. Position of Poland stagnated with some minor fluctuations between rank 38 (in 2016) to 60 (in 2007).

\section{Comparison of Countries in 2016}

When analyzing the latest values of GGI subindexes in 2016 (Figure 5), it is shown that all four countries reached excellent gender balance in subindexes education and health. However, all of them demonstrate very weak position in subindexes politics and economy in 2016. Poland stands as V4 leader, given its highest values in subindexes economy (0.69) and politics (0.238). The second follows the Czech Republic, with values in subindex economy (0.647) and politics (0.134). Slovakia, being the third, shows value for subindex economy 0.648 and for politics 0.093 . The worst position demonstrates Hungary with subindex economy (0.672) and politics $(0.035)$.

Figure 5: Subindexes economy, education, health and politics at Visegrad countries in 2016

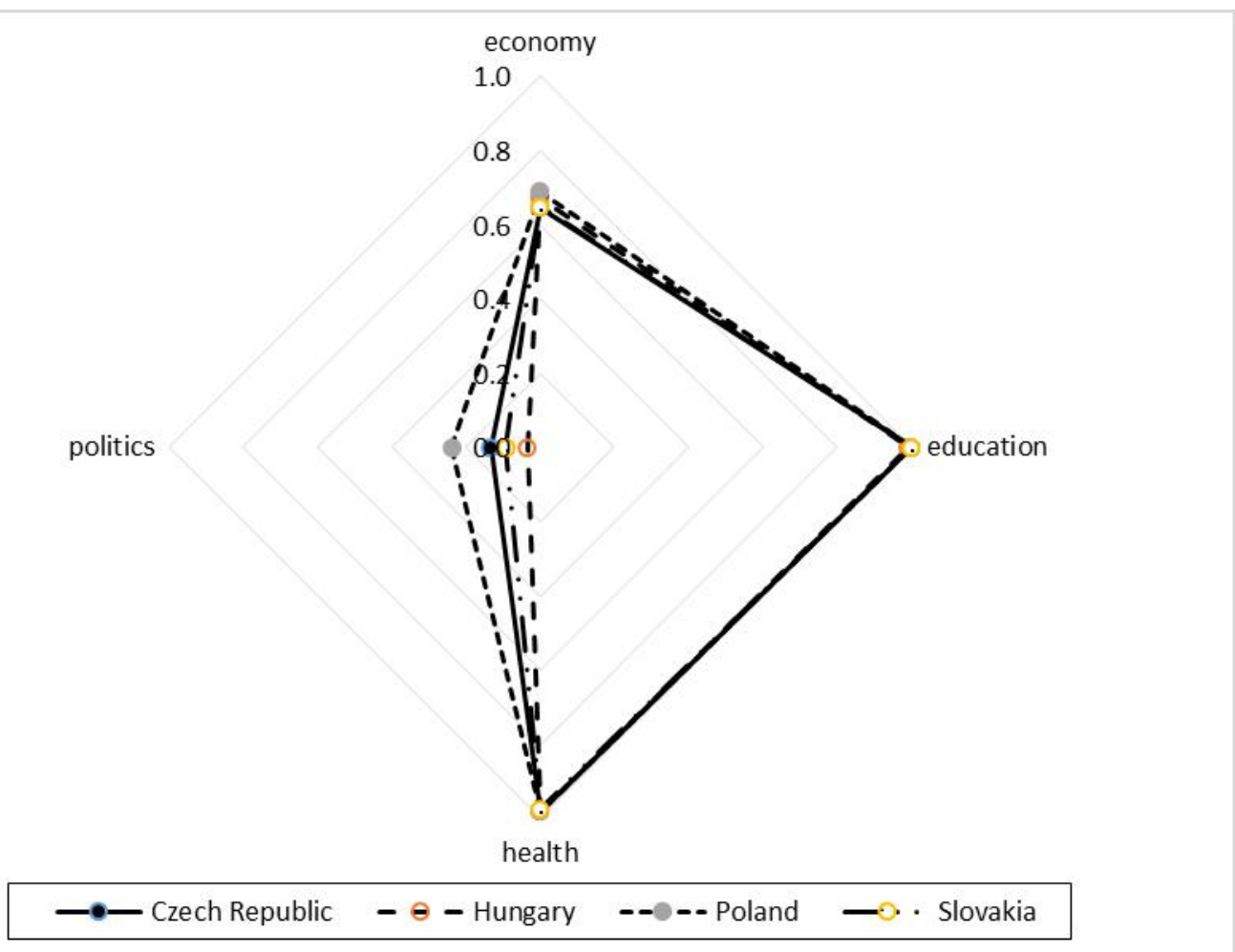

Source: Own analysis based on World Economic Forum (2016).

Figure 6 and Table 6 show analysis of all EU member countries in 2016. When analyzing position of Visegrad countries in dendrogram (Figure 6), we can see that three countries (Czech Republic, Hungary and Slovakia) are in the same cluster, the 1st cluster, together with Croatia, Cyprus, Greece, Romania, and Malta, countries that are on the periphery of economic importance within EU. While there are small difference among clusters in subindex education and subindex health, countries in the 1st cluster demonstrate the worst values not only in subindexes economy and politics, and overall GGI index, but also in country competitiveness (GCI), and in GDP per capita (Table 6). 
The last of V4 members, Poland, is a member of the 2nd cluster, with wide range of countries. Members of this cluster show better values of GGI subindexes as well as the whole GGI. Competitiveness and GDP per capita have higher values than those at the $1^{\text {st }}$ cluster, but show some small overlaps with countries of the 1 st cluster.

Figure 6: Dendrogram based on hierarchical cluster analysis (Euclidean distance, complete linkage method) of economics and politics subindexes for 2016

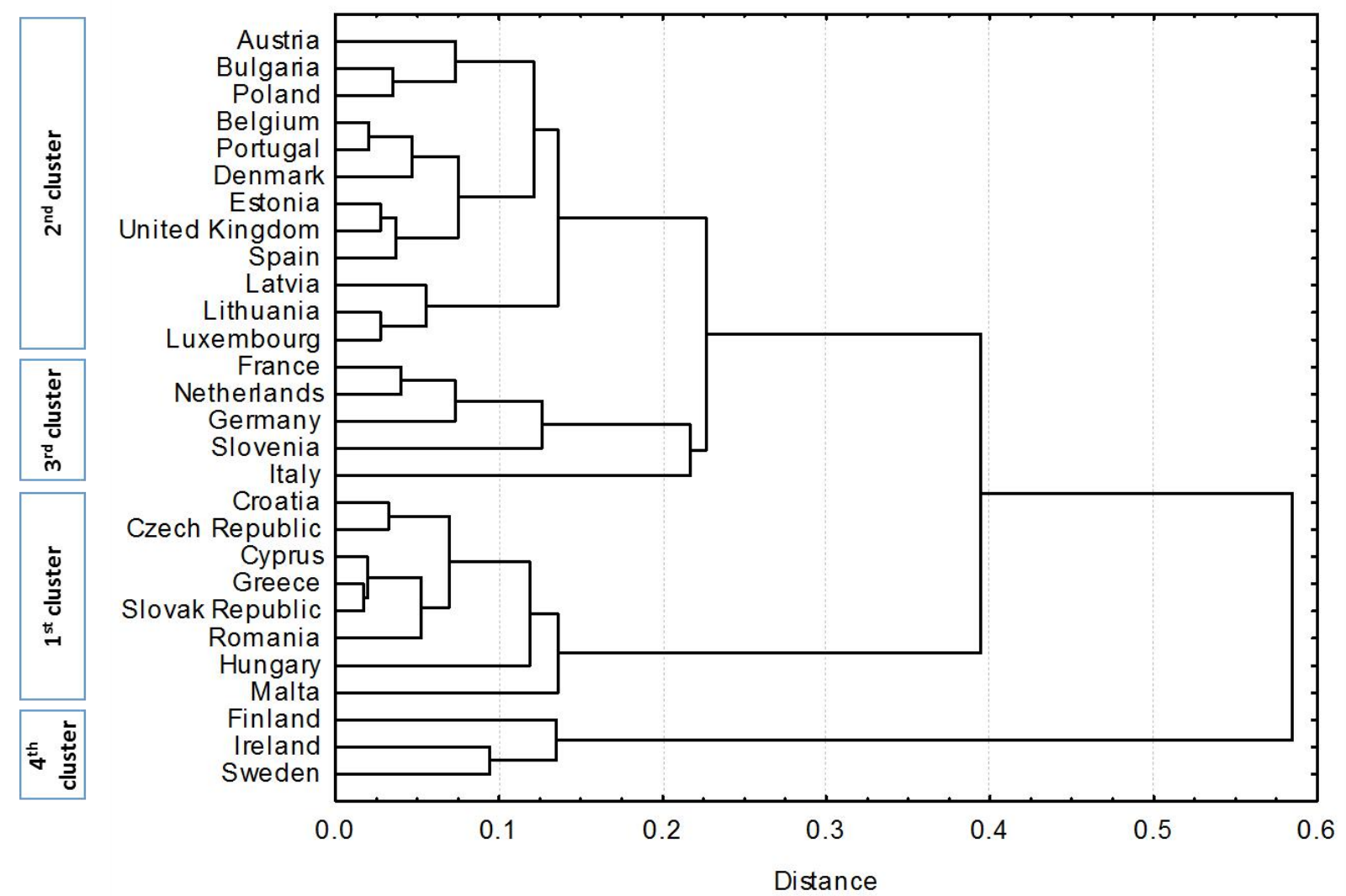

Source: Own analysis based on World Economic Forum (2016).

Table 6: Minimum (min) and maximum (max) of selected indicators in 2016 for four groups of countries identified on the basis of hierarchical cluster analysis

\begin{tabular}{lcccccccc}
\hline \multirow{2}{*}{ Indicator } & \multicolumn{2}{c}{ 1st cluster } & \multicolumn{2}{c}{ 2nd cluster } & \multicolumn{2}{c}{ 3rd cluster } & \multicolumn{2}{c}{ 4th cluster } \\
\cline { 2 - 8 } & $\min$ & $\max$ & $\min$ & $\max$ & $\min$ & $\max$ & $\min$ & $\max$ \\
\hline Economy & 0.595 & 0.699 & 0.650 & 0.785 & 0.574 & 0.784 & 0.709 & 0.802 \\
Education & 0.953 & 1.000 & 0.987 & 1.000 & 0.966 & 1.000 & 0.999 & 1.000 \\
Health & 0.970 & 0.979 & 0.970 & 0.980 & 0.970 & 0.980 & 0.974 & 0.980 \\
Politics & 0.035 & 0.154 & 0.212 & 0.335 & 0.331 & 0.428 & 0.486 & 0.607 \\
GGI & 0.664 & 0.700 & 0.716 & 0.755 & 0.719 & 0.786 & 0.797 & 0.845 \\
GCI & 4.00 & 4.72 & 4.44 & 5.49 & 4.39 & 5.57 & 5.18 & 5.53 \\
GDP (PPP) & 22.3 & 37.9 & 20.1 & 47.91 & 32.0 & 50.8 & 41.8 & 69.4 \\
(1000USD) & & & & & & & &
\end{tabular}

Source: Own analysis based on World Economic Forum (2016), Schwab (2016), Central Intelligence Agency (2017).

\footnotetext{
${ }^{1}$ The maximal value is without Luxembourg, which has the extremely high value 102 thousand USD per capita.
} 
Countries of the 3rd cluster have higher levels of subindex politics, but lower levels of subindex economy than countries of the 2 nd cluster. Their GGI indexes and their GCI are positioned at nearly the same interval as those of the 2 nd cluster members. However, their GDP per capital values are slightly higher.

The 4th cluster countries have the best values in all the subindexes of GGI, as well as, in the GGI index itself. Their competitiveness has the same values as the best performing members of the 3 rd cluster. However, their GDP per capita is higher.

Table 7: Estimated parameters of classification functions obtained by discriminant analysis of subindexes economy and politics in 2016

\begin{tabular}{lrrrr}
\hline \multirow{2}{*}{ Parameter } & \multicolumn{4}{c}{ Cluster } \\
\cline { 2 - 5 } & \multicolumn{1}{c}{ 1st } & \multicolumn{1}{c}{ 2nd } & \multicolumn{1}{c}{ 3rd } & \multicolumn{1}{c}{ 4th } \\
\hline Constant & -107.456 & -144.600 & -152.464 & -223.008 \\
Economy & 313.616 & 342.671 & 323.740 & 367.567 \\
Politics & 60.672 & 152.627 & 217.401 & 302.502 \\
\hline
\end{tabular}

Source: Own analysis based on World Economic Forum (2016).

Figure 7: Relationship between economy and politics subindexes in 2016

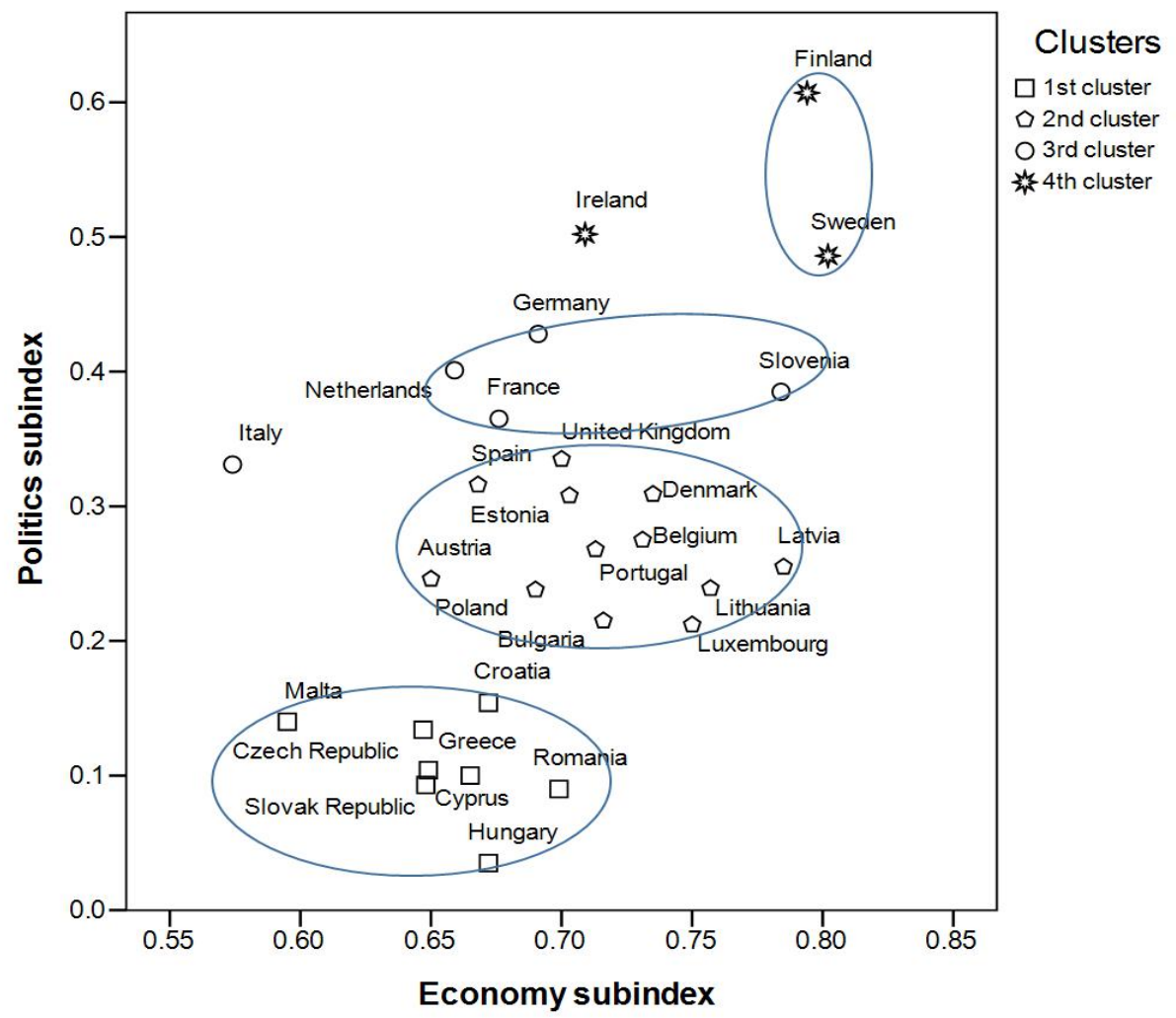

Source: Own analysis based on World Economic Forum (2016).

The group with lower competitiveness consists mostly from countries of 2nd cluster, while the group with higher competitiveness consists mostly from members of 3 rd cluster. Countries with the best GGI level (Sweden and Finland) demonstrate also the best competitiveness. Both of them are from the 4th cluster. When assessing Visegrad countries, Hungary and Slovakia are members of the worst EU group with low GGI and low GCI and are typical members of 1 st cluster. Poland demonstrates also typical features of the 2nd cluster members, moderate GGI and better GCI. However, the Czech Republic is showing different 
characteristics than most of the 1st cluster member, as it has low GGI, but as good level of GCI at the best performing members of the 2nd cluster in 2016.

Figure 8: Relationship between GCI and GGI in 2016

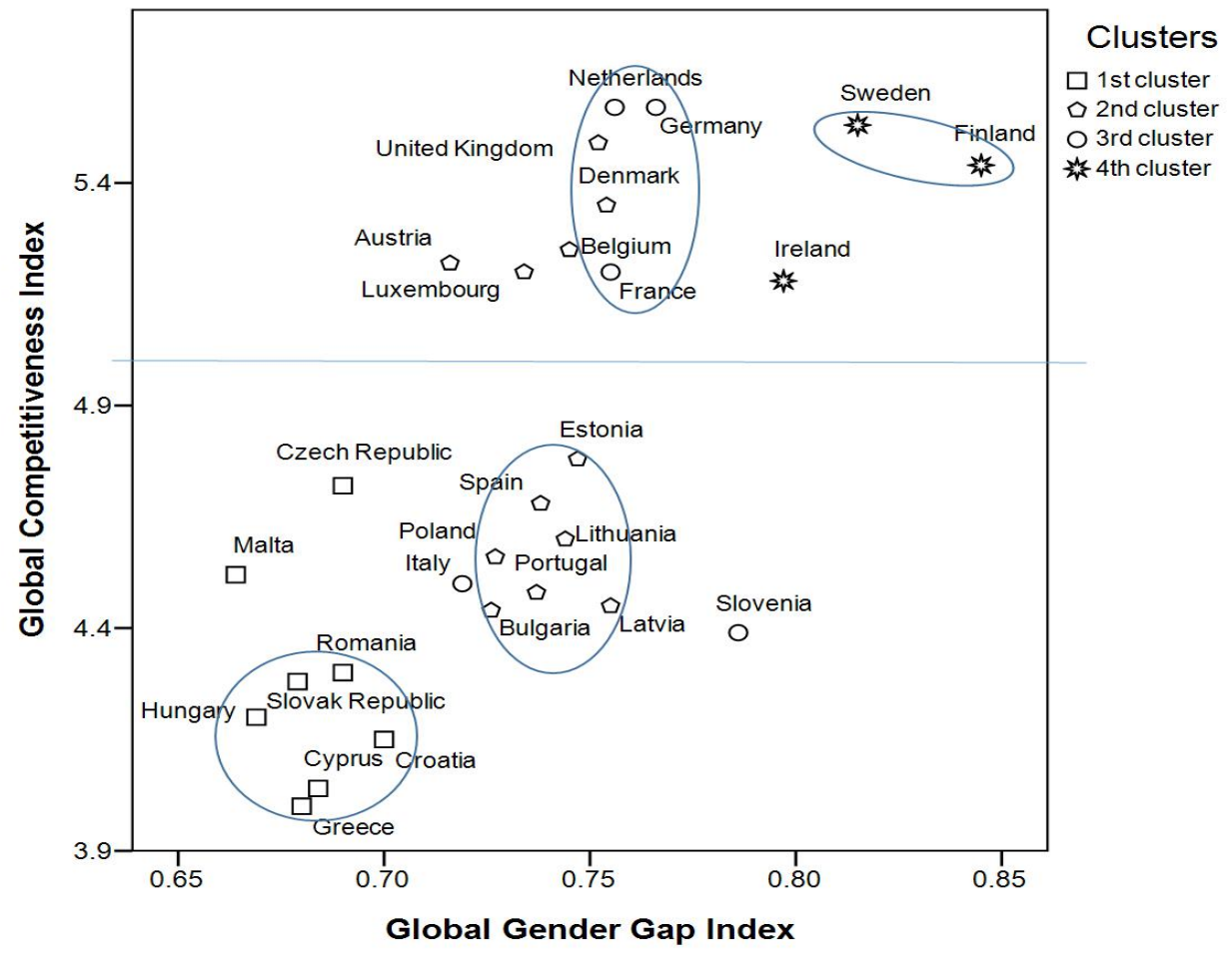

Source: Own analysis based on World Economic Forum (2016).

Figure 9: Relationship between GDP and GGI in 2016 (Except of Luxembourg and Ireland)

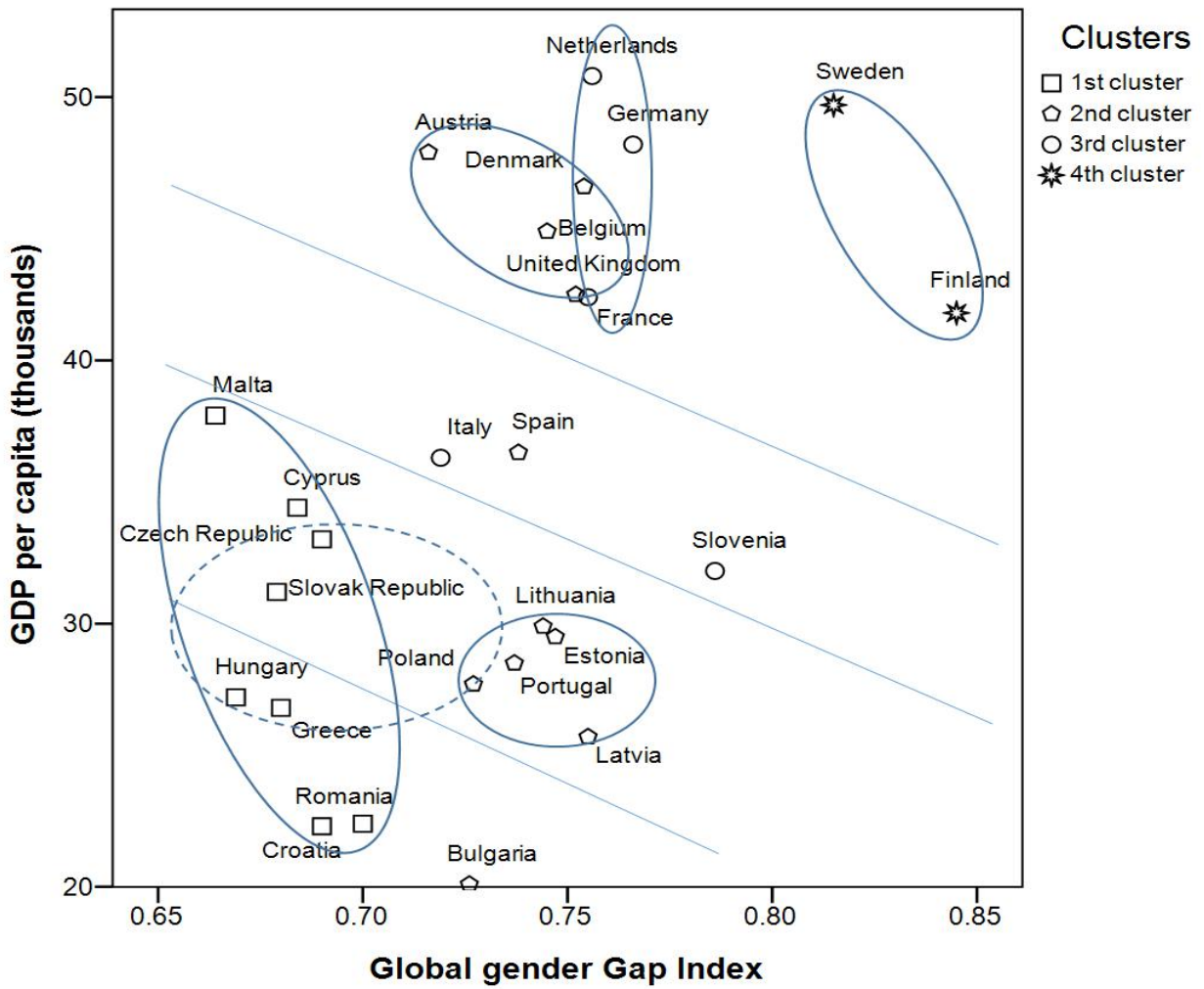

Source: Own analysis based on World Economic Forum (2016), World Bank (2016). 
Figure 9 shows relationship between country GDP per capita, and gender inequality, measured by GGI in 2016. Countries of the 1st cluster demonstrate lower values of GGI, but very varying levels of GDP per capita. The 2 nd second cluster of countries, with relatively same GGI values, was divided into two very separate groups by GDP per capita. The first group, with lower level of GDP is formed by Baltic countries, Portugal and Poland. The second group, with GDP per capita starting at 40 thousands USD. Countries of the 3rd cluster differ from those in the 4th cluster, but all of them are reaching similar levels of GDP per capita.

Visegrad countries, relatively to others EU countries, seem to be relatively close to each other, forming group with lower levels of GGI and lower levels of GDP per capita within EU in 2016.

\section{Conclusion}

The paper focuses on group of Visegrad countries given their recent joint history in political and economic development. The process of transformation started in all these countries in nearly the same time and all four countries were facing the same challenges in political, economic and society challenges to be able to join European Union and become economically competitive while maintaining social stability and social peace in these rapidly changing historical period since the beginning of 1990s. Given all the complexity, gender balance across society does not seem to be the priority at any of V4 countries. Even though they joined EU already in May 2004, all of them are lagging behind the gender equality compared to older EU members.

Gender inequality is both social and economic problem of countries. World Economic Forum introduced the respected Global Gender Gap index (GGI), measuring gender inequalities across most countries worldwide from 2006. In terms of GGI index development among Visegrad countries, only Poland shows stable improving trend. The rest of V4 countries has not made any significant improvements in period 2006-2016. Visegrad countries seem to have nearly closed the gender gap in the areas of Health and Survival and Educational Attainment. However, there are still significant inequalities in areas of Economic Participation and Opportunity and even worse situation stays in the areas of Political Empowerment. The gender inequality in economic participation and opportunities within Visegrad region have become of interest of researchers whose outcomes reflect the subindex evolution for these four countries. The subindex components like female labor force participation is reflected in uncovering discriminatory practices by employers against pregnant women and women with small children being decisive in women's decisions to postpone or forego childbearing (Mishtal, 2009), consequences of reconciling work with family care, like the negative and significant impact of motherhood reducing the likelihood of career choices in the Czech Republic (Brožová, 2015), negative impact of lengthy parental leave on chances to return to labor market in Hungary (Fodor and Kispeter, 2014), labor market discrimination of women due to their motherhood in Poland (Heinen and Wator, 2006), Czech society making parenthood a significant handicap for the social inclusion of women who are mothers of young children in the Czech Republic (Křrižková and Vohlídalová, 2009). Further wage discrimination war mirrored in proving motherhood wage penalty in Czech Republic (Žofková, 2014), gender discrimination explaining about half of the wage gap across Visegrad countries (Pailhe, 2000) and further gender biased remuneration studies (Vlachová, 2014; Mysíková, 2012; Balcar, 2012; Pytlíková, 2012; Kř́žková et al., 2010). The gender misbalanced ratio of senior officials and managers was investigated in cases of vertical segregation in business environment in the Czech Republic (Křečková, 2013; Křečková Kroupová, 2009), as well as also in the research institutions in Slovakia (Piscová, 2003). So, 
there are numerous studies supporting the subindex Economic Participation and Opportunity in all of its components. However, the political aspect of gender inequalities seems to be waiting for any interest of researchers.

When assessing relationship between gender balance (GGI) and country competitiveness (GCI) there seems to be dependence between values of GGI and values of GCI in most EU cases. Three Visegrad countries support this relationship when Hungary and Slovakia demonstrate both low values of GGI and GCI and Poland shows moderate level of both GGI and GCI within EU countries. However, the Czech Republic does not support this relationship statement, as even though its GGI is relatively low, its GCI is moderate. Positive correlation between gender equality and factors of competitiveness, sustainable competitiveness and standard of living (measured by level of GDP per capita) was identified in the OECD countries (Křečková Kroupová and Řezanková, 2016). However, the Czech Republic indicated very weak position and deteriorating trend. There seems to be mutual interdependency among these factors, without possibility to indicate the driving factors of correlation. The most important components of gender equality are apparently gender balance in political and economic participation (Křečková Kroupová and Řezanková, 2016).

In terms of analyzing relationship between GGI and GDP per capita, in most EU cases seems that with rising GGI rises also GDP per capita. In this respect V4 are supporting this observation.

\section{Acknowledgements}

This article was processed with contribution of long-term institutional support of research activities by the Faculty of Informatics and Statistics and Faculty of International Relations, University of Economics, Prague.

\section{References}

[1] Balcar, J., Filipová, L., Machová, Z. 2012. Gender wage gap in the Czech Republic: First descriptive analysis based on survey 2011. Národohospodářský obzor - Review of Economic Perspectives, vol. 12, iss. 3, pp. 151-167. DOI: 10.2478/v10135-012-0007-5.

[2] Brožová, D. 2006. Diskriminace žen v ekonomické teorii vybrané problémy. [The economics of sex discrimination Selected problems]. Politická ekonomie, vol. 54, iss. 5, pp. 646-660. DOI: https://doi.org/10.18267/j.polek.577.

[3] Brožová, D., Stroukal, D. 2015. Teorie preferencí a kariéra žen na českém trhu práce. [Preference theory and women's career choice on the Czech labor market]. Politická ekonomie, vol. 63, iss. 3, pp. 382-399. DOI: https://doi.org/10.18267/j.polek.1009.

[4] Central Intellingence Agency. 2017. GDP - per capita (PPP). The World Factbook. [cit. 29-04-2017] https://www.cia.gov/library/publications/the-worldfactbook/rankorder/2004rank.html.

[5] Fodor, E., Kispeter, E. 2014. Making the 'reserve army' invisible: Lengthy parental leave and women's economic marginalisation in Hungary. European Journal of Women's Studies, vol. 21, iss. 4, pp. 382-398.

[6] Heinen, J., Wator, M. 2006. Child care in Poland before, during, and after the transition: Still a women's business. Social Politics: International Studies in Gender, State \& Society, vol. 13, iss. 2, pp. 189-216.

[7] Jolliffe, D., Campos, N.F. 2005. Does market liberalisation reduce gender discrimination? Econometric evidence from Hungary, 1986-1998. Labour Economics, 2005, vol. 12, iss. 1, pp. 1-22. 
[8] Křečková, Z. 2013. Women on boards: The perspective of Czech and Slovak Republics within European context. Slovak Scientific Journal Management: Science and Education, vol. 2, iss. 1, pp. 40-42.

[9] Křečková Kroupová, Z. 2009. The role of women in international business world and in the Czech Republic. Acta Oeconomica Pragensia, vol. 17, iss. 4, pp. 34-41. DOI: https://doi.org/10.18267/j.aop.277.

[10]Křečková Kroupová, Z., Řezanková, H. 2016. Vztah genderové mezery, konkurenceschopnosti a udržitelnosti ekonomiky - postavení České republiky v mezinárodním srovnání. [Relationship of gender gap, competitiveness and sustainability of economy position of the Czech Republic in international comparison]. Politická ekonomie, vol. 64, iss. 4, pp. 468-491. DOI: https://doi.org/10.18267/j.polek.1083.

[11]Kř́žzová, A., Vohlídalová, M. 2009. Parents in the labor market: Between work and care. Sociologický časopis - Czech Sociological Review, vol. 45, iss.1, pp. 31-60.

[12]Kř́žzová, A., Penner, A.M., Petersen, T. 2010. The legacy of equality and the weakness of law: Within-job gender wage inequality in the Czech Republic. European Sociological Review, vol. 26, iss.1, pp. 83-95.

[13] Mishtal, J.Z. 2009. Understanding low fertility in Poland: Demographic consequences of gendered discrimination in employment and postsocialist neoliberal restructuring. Demographic Research, vol. 21, pp. 599-626. DOI: 10.4054/DemRes.2009.21.20.

[14]Mysíková, M. 2012. Gender wage gap in the Czech Republic and central European countries. Prague Economic Papers, vol. 21, iss. 3, pp. 328-346. DOI: https://doi.org/10.18267/j.pep.427.

[15]Pailhe, A. 2000. Gender discrimination in Central Europe during the systemic transition. Economics of Transition, vol. 8, iss. 2, pp. 505-535.

[16]Picka, J. 2014. Problém „public-private pay gap“ v České republice. [The public-private pay gap in the Czech Republic]. Politická ekonomie, vol. 62, iss. 5, pp. 662-682. DOI: https://doi.org/10.18267/j.polek.975.

[17]Piscová, M. et al. 2003. Gender in Science-Women in Science in Slovakia. SociológiaSlovak Sociological Review, vol. 6, pp. 579-598.

[18]Pytlíková, M. et al. 2012. Gender Wage Gap and Discrimination in the Czech Republic. Ostrava: VŠB-TU Ostrava, Ekonomická fakulta, 2012. ISBN 978-80-248-2940-1.

[19] Schwab, K. (ed.) 2016. The Global. Competitiveness Report 2016-2017. Geneva: World Economic Forum. [cit. 29-04-2017] http://www3.weforum.org/docs/GCR20162017/05FullReport/TheGlobalCompetitivenessReport2016-2017_FINAL.pdf.

[20] Vlachová, H. 2014. Genderová platová mezera v soukromém a veřejném sektoru České republiky. [Gender pay gap in private and public sectors of the Czech Republic]. Acta Oeconomica Pragensia, vol. 22, iss. 5, pp. 89-100. DOI: https://doi.org/10.18267/j.aop.454.

[21] World Economic Forum. 2006. The Global Gender Gap Report 2006. Geneva: World Economic Forum. [cit. 29-04-2017] http://reports.weforum.org/the-global-gender-gapreport-2006-info/.

[22] World Economic Forum. 2007. The Global Gender Gap Report 2007. Geneva: World Economic Forum. [cit. 29-04-2017]

http://www3.weforum.org/docs/WEF_GenderGap_Report_2007.pdf. 
[23] World Economic Forum. 2008. The Global Gender Gap Report 2008. Geneva: World Economic Forum. [cit. 29-04-2017]

http://www3.weforum.org/docs/WEF_GenderGap_Report_2008.pdf.

[24] World Economic Forum. 2009. The Global Gender Gap Report 2009. Geneva: World Economic Forum. [cit. 29-04-2017]

http://www3.weforum.org/docs/WEF_GenderGap_Report_2009.pdf.

[25] World Economic Forum. 2010. The Global Gender Gap Report 2010. Geneva: World Economic Forum. [cit. 29-04-2017]

http://www3.weforum.org/docs/WEF_GenderGap_Report_2010.pdf.

[26] World Economic Forum. 2011. The Global Gender Gap Report 2011. Geneva: World Economic Forum. [cit. 29-04-2017]

http://www3.weforum.org/docs/WEF_GenderGap_Report_2011.pdf.

[27] World Economic Forum. 2012. The Global Gender Gap Report 2012. Geneva: World Economic Forum. [cit. 29-04-2017]

http://www3.weforum.org/docs/WEF_GenderGap_Report_2012.pdf.

[28] World Economic Forum. 2013. The Global Gender Gap Report 2013. Geneva: World Economic Forum. [cit. 29-04-2017]

http://www3.weforum.org/docs/WEF_GenderGap_Report_2013.pdf.

[29] World Economic Forum. 2014. The Global Gender Gap Report 2014. Geneva: World Economic Forum. [cit. 29-04-2017] http://www3.weforum.org/docs/GGGR14/GGGR_CompleteReport_2014.pdf.

[30] World Economic Forum. 2015. The Global Gender Gap Report 2015. Geneva: World Economic Forum. [cit. 29-04-2017]

http://www3.weforum.org/docs/GGGR2015/cover.pdf.

[31] World Economic Forum. 2016. The Global Gender Gap Report 2016. Geneva: World Economic Forum. [cit. 29-04-2017]

http://www3.weforum.org/docs/GGGR16/WEF_Global_Gender_Gap_Report_2016.pdf.

[32]Žofková, M., Stroukal, D. 2014. Odhad mzdové srážky za mateřství v České republice. [Estimating the motherhood wage penalty in the Czech Republic]. Politická ekonomie, vol. 62, iss. 5, pp. 683-700. DOI: https://doi.org/10.18267/j.polek.976. 